Journal of Management Development, Volume 28, Issue 6, 2009, Pages 542-549

This article is (c) Emerald Group Publishing and permission has been granted for this version to appear here (https://dspace.lib.cranfield.ac.uk/index.jsp). Emerald does not grant permission for this article to be further copied/distributed or hosted elsewhere without the express permission from Emerald Group Publishing Limited.

\title{
Role as a Mechanism for Rotating Leadership in a Group
}

\author{
By \\ A.G. Sheard \\ Vice President - Fan Technology \\ Fläkt Woods Limited, \\ Tufnell Way, \\ Colchester, \\ CO4 5AR, \\ England. \\ Tel: $+44(0) 1206244420$ \\ Fax: +44(0)1206 244449 \\ Email: geoff.sheard@flaktwoods.com \\ and \\ A.P. Kakabadse \\ Deputy Director, Cranfield School of Management \\ Professor of International Management Development \\ Cranfield School of Management, \\ Cranfield, \\ Bedfordshire, \\ MK43 OAL. \\ Tel: $+44(0) 1234754400$ \\ Fax: +44 (0) 1234752382 \\ Email: a.p.Kakabadse@cranfield.ac.uk
}

and

N.K. Kakabadse

Professor in Management \& Business Research

Northampton Business School,

The University of Northampton, Park Campus, C21

Boughton Green Road

Northampton, NN2 7AL, United Kingdom

Tel: $+44(0) 1604892197$

Fax: $+44(0) 1604721214$

nada.kakabadse@northampton.ac.uk

Submitted to the Journal of Management Development 


\section{Role as a Mechanism for Rotating Leadership in a Group}

Keywords: Leadership, Leadership Roles, Networked Organisation,

Organisational Structure.

Word Count: 2,570 (Excluding References)

Category: Research Paper

\section{Purpose}

This study proposes that executives need to be prepared to adopt roles as a mechanism for rotating leadership if those groups' of which they are a part are to perform to their full potential.

\section{Design / Methodology / Approach}

A validated framework provides insight into the leadership roles executives can adopt when part of formal, informal and temporary groups. The methodology adopted is qualitative, focusing on application of previously developed frameworks.

\section{Findings}

Adopting a role is found to enable the rotation of leadership within a group that in turn facilitates development of the group.

\section{Research Limitations / Implications}

A one-organisation intensive case study of a multinational engineering company engaged in the design, development and manufacture of rotating turbomachinery provides the platform for the research. The frameworks will require validating in organisations of different demographic profiles.

\section{Practical Implications}

The concepts advanced, and implications discussed, provide an insight into the role-based nature of leadership. The practical steps individual executives can take to adopt a role, and in so doing develop the group of which they are a part, are highlighted.

\section{Originality / Value}

This paper is an investigation into, and study of, the process by which executives adopt roles as a mechanism for rotating leadership within a group. In so doing, it is suggested that executives contribute more positively to the development of the groups' of which they are a part by being more adaptive and responsive to changes in their surrounding context. 


\subsection{Introduction}

In this article the authors starting premise is that anyone who presumes to step into a leadership role can learn to distribute and rotate the tasks of leadership, helping create and develop groups to solve organisational problems they would find difficult to solve alone. The purpose of this article is to present leadership in terms of complimentary roles, with choice of role being dependent upon context. The objective in doing so is to make the reader aware of the roles available, and the changing relative importance of those roles as a group develops. The establishment of roles within a group is dependent upon a measure of self-discovery on the part of its members, combined with a perception of both the group's and wider organisation's needs as a whole, Sheard (2007), Sheard et al (2010).

In this article the concepts advanced comprise an extension to a branch of the self development school of leadership known as the "functional" approach to leadership. The functional approach to leadership focuses on the ability of an individual to influence, and be influenced by, a group in the implementation of a common task (Bass, 1985; Graen, 1976; Graen \& Scandura, 1987; House, 1977). In order for leadership responsibilities to be met, certain functions need to be performed with a function being defined as what you do as contrasted with what you are or what you know (Adair, 2003: 36). Aspects of the current study relating to group development and role theory are respectively extensions theory reported by Tuckman (1965) and Parsons (1951).

\subsection{The Study}

The inquiry into the extent to which a role-based perspective can provide insight into how leadership within a group can be shared and rotate was undertaken within a manufacture of rotating turbomachinery. The longitudinal study that underpins this articles has been cured out over ten years and respectively employed ethnography, action research and collaborative inquiry methodologies (Sheard \& Kakabadse 2002; 2006; 2007). 
Qualitative inquiry uses various techniques in working to capture the nuances and complexity of the social situation under study (Flick, 1998; Johnson \& Harris, 2002). In the current inquiry the social situation under study is the groups' executives form. Complexity of the social situations of interest is the mechanism by which executives share and rotate leadership within those groups.

\subsection{The Six Stages of Role Rotation}

In this article the authors contemplate leadership in terms of four roles, and group development in terms of six stages of group development. Executives consciously choose to adopt one of the roles available, and attempt to remain aware of the stage a group has reached though its development. Contemplating leadership in terms of role and group development in terms of stage facilitates the rotation of leadership within a group, and as a consequence the progression of a group though the stages of its development. Before considering how leadership rotates amongst group members however, it is first necessary to clarify why it is reasonable to conceptualise leadership in terms of role and group development in terms of stages.

\subsection{Group Development}

Over the last five decades, scholars studying group behavior have advocated various models of group development and whilst these models share some similarities, they also differ quite significantly from each other (Chimambaram \& Bostrom, 1996). The most widely accepted class of group development models' is, however, the linear progressive models that advocate a group development sequence. The concept of a group development sequence separates out two aspects of group functioning; the task activity a group is undertaking and the process of a group's life. A development sequence focuses on the process of group life, asserting that a common development sequence exists for all groups. Different scholars advocate different stages in a group's development, however the most widely accepted comprises five (Tuckman, 1965; Tuckman \& Jensen, 1977): 
(1) Orientation / testing / dependence.

(2) Conflict.

(3) Group cohesion.

(4) Functional role-relatedness.

(5) Individual loss and mourning.

These five stages may be labelled mobilisation, confrontation, coming together, behaving as one and mourning the past. During the mobilisation stage group members get to know each other and establish more personable relationships. During the confrontation stage conflict happens. Conflict could emerge over rival leadership challenges or simply because of interpersonal behaviour. The group could split at this stage. Emerging with a single leader, the group moves into the coming together stage. Here norms of behaviour and group cohesiveness are established. New group standards are set for members and roles are determined. The behaving as one stage occurs when members start performing tasks together. Role clarity has been established and members are now working together in a cooperative and complimentary manor. The mourning the past stage occurs as members realise that the group is about to complete the task for which it was originally created. They feel a sense of loss at the imminent destruction of the social system that the group has become.

The concept of a linear development sequence in small groups is important as it establishes the existence of generic stages through which all groups pass. During the course of their research however (Sheard \& Kakabadse, 2004), the authors have observed that the vast majority of groups do not pass smoothly through the stages of a linear group development sequence. In practice individuals' opt-out, groups regress and in many cases never perform. During the course of their research, the authors recognised that a linear group development sequence could more usefully be considered in terms of a process, specifically a process with two breakdown points. 
The first breakdown point occurs as a group attempts to negotiate the transition out of the mobilisation and into the confrontation stage. The breakdown occurs as the extent of the nonshared assumptions between members becomes clear and each individual asks themselves "do I agree with what this group is being asked to do?" Not everyone will agree, and some will opt out. The second breakdown point occurs as a group attempt to negotiate the transition out of the coming together and into the behaving as one stage. Individuals ask themselves "do I accept the role I will have to play to work in this group?" The sudden realisation of what working in the group will actually mean in practical terms results in some instinctively answering "no". As a consequence the group will slip back into conflict, entering a new stage one step forward, two steps back (Kakabadse, 1987a; 1987b; Sheard \& Kakabadse, 2004).

The one step forward, two steps back stage models the regressive behaviour so often seen in groups as in order to leave it all must agree to do so. A reason why many groups never perform to their full potential is that the group members do not wish it to. Many groups never progress beyond the one step forward, two steps back stage, and that is why they perform so badly compared to the potential that capability of individual members would imply the group to be capable of. By identifying two breakdown points and an additional stage, one step forward, two steps back stage, the authors have been able to create an "integrated" group development process, Figure One. Integrated on the basis that it identifies all stages of, and breakdown points within, a group's development:

Stage One: Mobilising.

Stage Two: Confrontation.

Stage Three: Coming together.

Stage Four: One step forward, two steps back.

Stage Five: Behaving as one.

Stage Six: Mourning the past. 


\section{Take in Figure One}

\subsection{Leadership Roles}

When first working with executives and boards of directors the authors were consistently surprised by the poor performance of the groups involved given the potential capability of their members. Typically the groups studied would comprise members who were both highly intelligent and hard working. Despite these necessary attributes for success, the majority of groups performed well below the level anticipated.

Over time the authors observed that amongst those groups that did perform, a common characteristic was present: members divided leadership responsibility into blocks of tasks. As the authors studied the highest performing groups, it became apparent that members were not only dividing the tasks of leadership, but were also adapting their behaviour. In so doing members were coordinating their leadership action, with specific "bundles" of behaviour being associated with generic sets of tasks enabling members to "know" who should do what without the need for extensive debate (Sheard \& Kakabadse, 2007).

The authors realised that members were not just adapting behaviour in response to others who happened to be in one particular group. They were choosing to adopt bundles of behaviours that could be characterised as "roles" that were generic across multiple groups with different memberships. The authors realised that just as a group passes through generic stages of development that are applicable to any group, so group members adopt roles that are also applicable in any group. The concept of group members choosing roles complimentary to those of other members therefore separates out two aspects of group functioning; the task activity a group is undertaking and the group's leadership. 
Having recognised the existence of generic roles, the authors focused on characterising them. Four distinctly different, yet complimentary, roles emerged from the research, characterised using the metaphors king, tactician, elder and warrior. A group's king is defined as the member who is accountable for delivery of a group's goal. A group's tactician is defined as the publicly appointed leader of the group who is responsible for delivery of its goal. An elder is a group member who undertakes to build a network of relationships with other group members. A group's warriors derive their legitimacy to lead other group members from the formal allocation of responsibility to deliver a specific task by the group's tactician.

When characterising the four roles the authors observed that the king and warriors consciously choose to give their attention to the group's goal. In contrast the tactician and elders consciously choose to give their attention to the establishment of good working relationships within the group. As such the king and warriors were focused on goal attainment in contrast to the tactician and elders who were focused on relationship building.

At the same time elders and warriors were unconsciously attracted to issues within the group. In contrast the king and tactician were seeing the bigger picture as a consequence of their unconscious interest in the group's impact on the wider organisation. As such elders and warriors were oriented towards the group in contrast to the king and tactician who were oriented towards the wider organisation.

It is the combination of focus (goal attainment versus relationship building) and orientation (intra group verse inter group) that define the four roles of leaders, king, tactician, elder and warrior, Figure Two. The king, tactician, elder and warrior roles collectively cover the need to attain a goal and build relationship plus work both within a group and the wider organisation. Any single 
individual would find it difficult to do all four. However, if different individuals choose different roles then it is possible for a group to do what no individual within it could do alone.

\section{Take in Figure Two}

\subsection{Role Rotation}

Whilst acknowledging that there are actions leaders take that spring from a flash of genius, the authors' research has identified that the most effective leaders focus on eight key functional areas (Sheard \& Kakabadse 2004):

- Clearly defining goals.

- Priorities.

- Roles \& Responsibilities.

- Self awareness.

- Group dynamics.

- Communication.

- Context.

- Infrastructure.

The conceptual foundations of the eight key functional areas, referred to as "key factors" are rooted within the work of Adair (1986). It has been postulated by Adair (1986: 112) that "groups" at the most generic level share certain common needs.

During the course of their research (Sheard \& Kakabadse, 2006) the authors have characterised the four roles in terms of the relative importance of the eight key factors, Figure Three. In so doing insight into what group members should do when adopting each role is provided. The authors also characterised the six stages of a group's development in terms of the relative importance of the eight key factors (Sheard \& Kakabadse, 2004), Figure Three. In so doing insight is provided into what is important to a group as it progresses through its development.

Take in Figure Three 
It is the duel characterisation of roles and stages in terms of the importance of key factors that in turn provides insight into how leadership should rotate. As an individual joins a group they have a choice of roles, with choice being dependent upon their reading of context. Having chosen a particular role, the key factors associated with that role become the focus of their action. The importance of those key factors changes as a group passes though its development process. By remaining aware of the stage a group has reached, the changing importance of key factors associated with the role adopted is highlighted. It is insight into the changing relative importance of key factors associated with the role adopted as a group progresses though its development sequence that identifies how leadership should rotate and to whom.

\subsection{Conclusions}

A new role-based leadership framework and its practical application are presented. Leadership is described in terms of four complimentary roles, king, warrior, tactician and elder with each group member adopting one of the four roles. None are characterised as adopting purely follower roles. Once the responsibilities and tasks of leadership are shared, then the group amongst whom they are shared must work together.

A group's development is described in terms of six stages, mobilising, confrontation, coming together, one step forward two steps back, behaving as one and mourning the past. The relative importance of each role at each stage of a group's development is clarified by characterising both in terms of eight key factors. The duel characterisation provides insight into which roles are most important at each stage of a group's development, clarifying whom leadership should rotate from and too. 


\section{References}

Adair, J. (1986), Effective Team Building, Gower Publishing Ltd, Aldershot.

Adair, J. (2003), The Inspirational Leader, Kogan Press, London.

Bass, B.M. (1985), Leadership and Performance Beyond Expectations, Free Press, New York.

Chidambaram, L. \& Bostrom, R.P (1996), "Group Development (I): A Review and Synthesis of Development Models”, Group Decision and Negotiation, Vol. 6, pp 159-187.

Flick, U. (1998), An Introduction to Qualitative Research: Theory, Method and Application, Sage, London.

Graen, G. (1976), "Role Making Processes Within Complex Organisations", In Dunnette, M.D. (Ed.), Handbook of Industrial and Organisational Psychology, pp 1201-1245, Rand McNally, Chicago.

Graen, G.B. \& Scandura, T.A. (1987), "Towards a Psychology of Dyadic Organising", in Cummings, L.L. \& Staw, B.M. (Eds.), Research in Organisational Behaviour, pp 175-208, JAI Press, Greenwich.

House, R.J. (1977), “A 1976 Theory of Charismatic Leadership”, in Hunt, J.G. \& Larson, L.L. (Eds.), Leadership: The Cutting Edge, pp 189-207, Southern Illinois University Press, Carbondale.

Johnson, P. \& Harris, D. (2002), "Qualitative and Quantitative Issues in Research Design" in Partington, D. (Ed.), Essential Skills for Management Research, pp 99-116, Sage, London.

Kakabadse, A.P. (1987a), "The Syntax Corporation Part One", in Kakabadse, A.P. \& Tyson, S. (Ed.), Cases In European Human Resource Management, Heinemann, London, pp. 65 - 69.

Kakabadse, A.P. (1987b), "The Syntax Corporation Part Two, Three, Four \& Five", in Kakabadse, A.P. \& Tyson, S. (Ed.), Cases In European Human Resource Management - Teachers Guide (Second Edition), Routledge, London, pp. 54 -83.

Parsons, T. (1951), The Social System, The Free Press, New York.

Sheard, A.G. (2007), An Examination of Leadership Development: A Role Based Perspective, PhD Thesis, University of Northampton, Northampton, England.

Sheard, A.G. \& Kakabadse, A.P. (2002), "Key Roles of the Leadership Landscape", Journal of Managerial Psychology, Vol. 17 No. 2, pp. 129-144.

Sheard, A.G. \& Kakabadse, A.P. (2004), "A Process Perspective on Leadership and Team Development", Journal of Management Development, Vol.23, No. 1, pp. 1-106, Monograph Edition.

Sheard, A.G. \& Kakabadse, A.P. (2006), "Mapping the Transitional Experience of Switching Leadership Roles", Accepted for Publication in the Leadership and Organisational Development Journal.

Sheard, A.G. \& Kakabadse, A.P. (2007), "A Role Based Perspective on Leadership as a Network of Relationships", Accepted for Publication in the Journal of Management Development. 
Sheard, A.G., Kakabadse A.P. \& Kakabadse N.K. (2010), Leadership Teams: Developing and Sustaining High Performance, Palgrave Macmillan, Basingstoke.

Tuckman, B.W. (1965), "Development Sequences in Small Groups”, Psychology Bulletin, Vol. 63 No. 6, pp 384-399.

Tuckman, B.C. \& Jensen M.C. (1977), "Stages of Small Group Development Revisited”, Group and Organisational Studies, Vol. 2 No. 4, pp 419-427. 


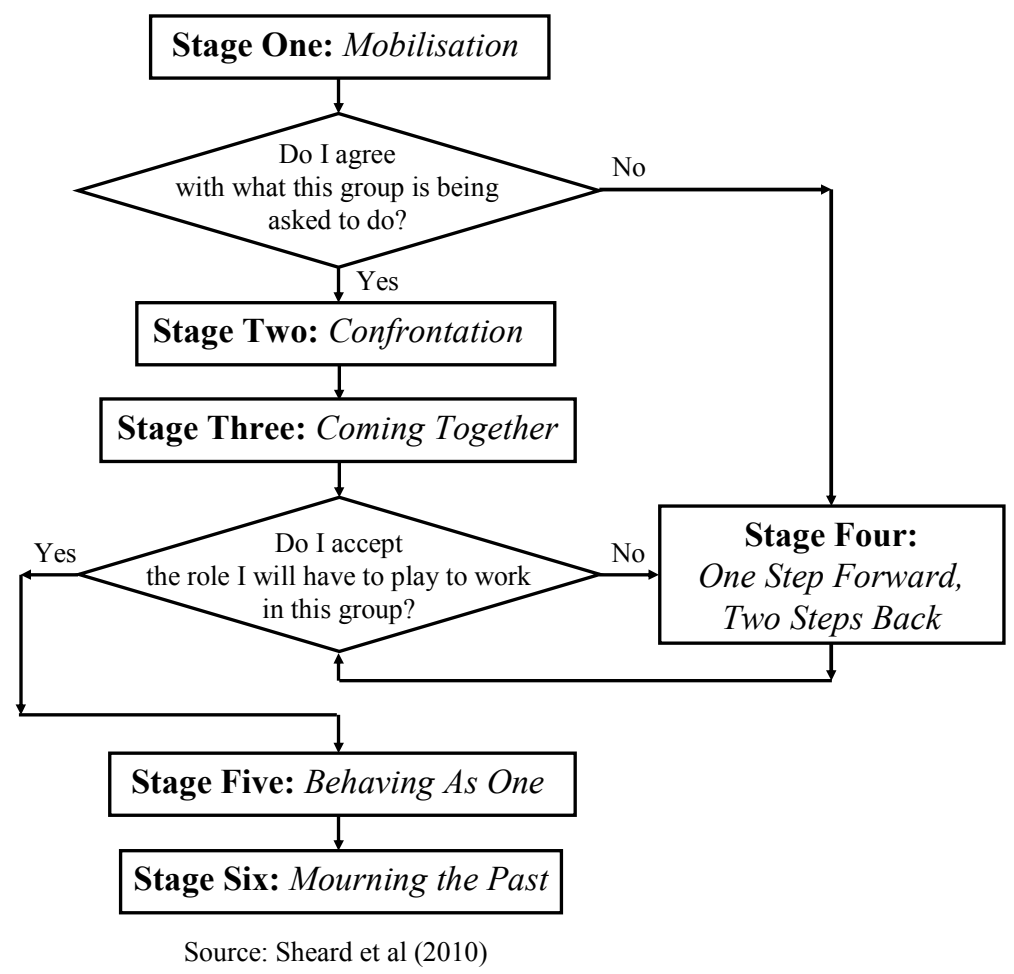

Figure 1: The integrated group development process.

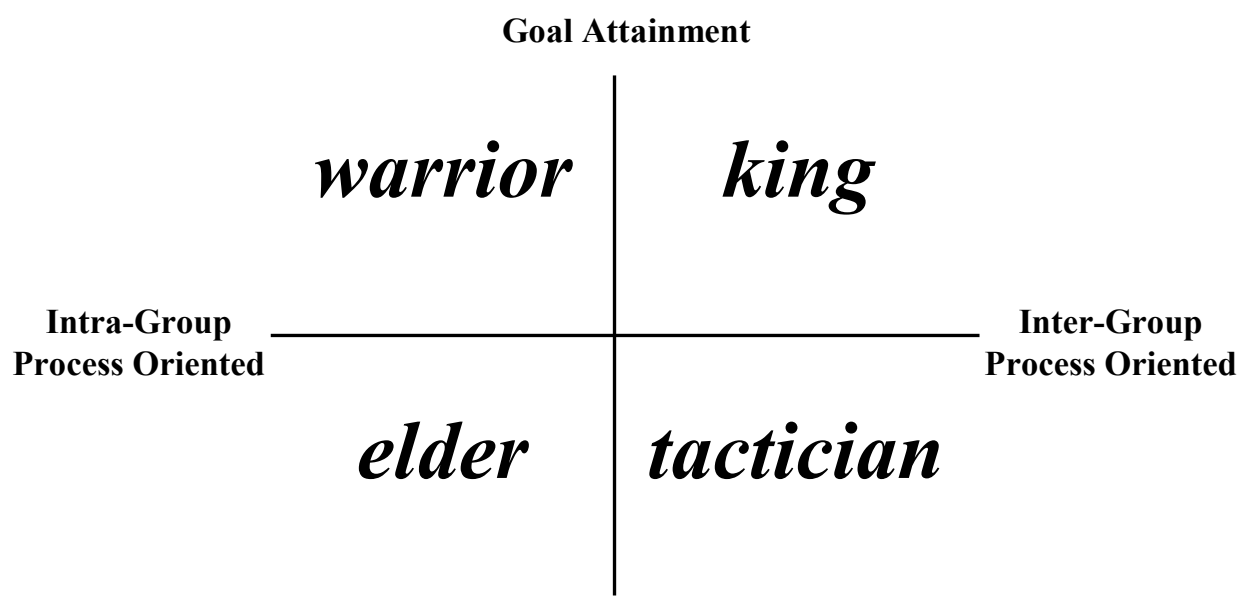

Relationship Building

Source: Compiled by the authors.

Figure 2: The four roles of leaders. 


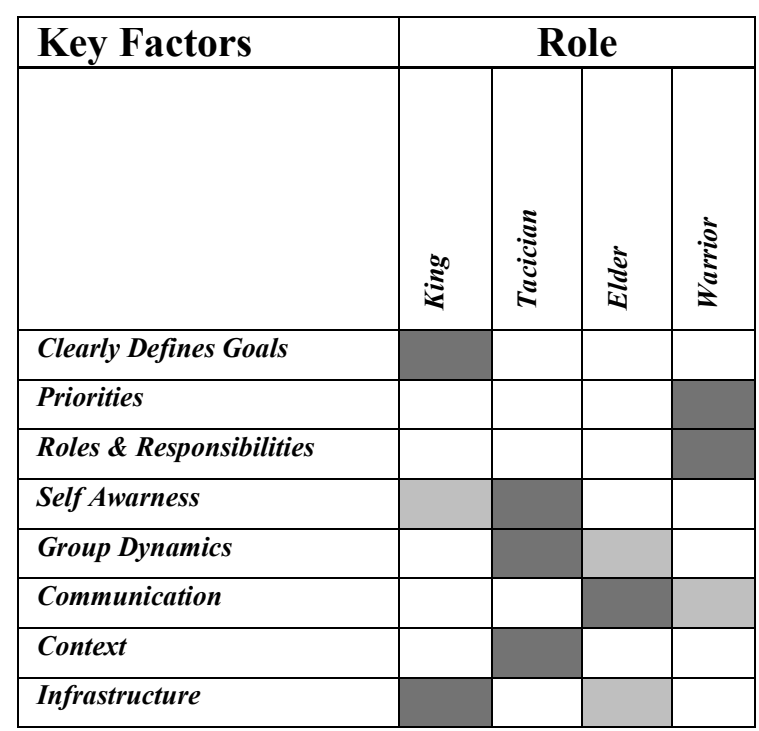

\begin{tabular}{|c|c|c|c|c|c|}
\hline \multicolumn{6}{|c|}{ Group Development Stage } \\
\hline 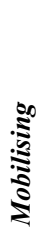 & $\frac{5}{5}$ & 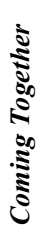 & 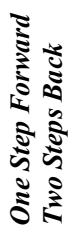 & 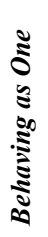 & 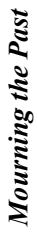 \\
\hline & & & & & \\
\hline & & & & & \\
\hline & & & & & \\
\hline & & & & & \\
\hline & & & & & \\
\hline & & & & & \\
\hline & & & & & \\
\hline & & & & & \\
\hline
\end{tabular}

Priority Key Factor

Supporting Key Factor

Unimportant Key Factor

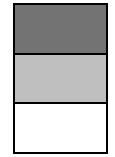

Source: Complines by the authors.

Figure 3: The relative imporance of the eight key factors to both role and stages of a group's development. 